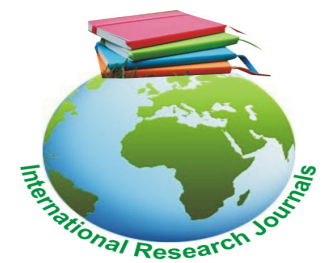

International Research Journal of Arts and Social Sciences, Vol. 2(9) pp. 220-227, October, 2013 DOI: http:/dx.doi.org/10.14303/irjass.2013.067

Available online http://www.interesjournals.org/IRJASS

Copyright (c) 2013 International Research Journals

Review

\title{
Modern theatre: actor's musical requirements in the educational process of Kazakhstan
}

\author{
*Kabyl Khalykov and Yeslam Nurtazin \\ 407/54, Seifullin str., 050050, Almaty, Kazakhstan \\ ${ }^{*}$ Corresponding author Email:kabylkh@gmail.com
}

Accepted October 14, 2013

\begin{abstract}
The article is devoted to the problem of investigation of the popular genre of musical and its development, particularities of the specifics of the musical theatre in its merger with the contemporary music, comparison and application of the classical elements of choreographic art. At this stage of the development of this genre, there is a problem aroused of specific merging of economics and art, in other words, "popularization" of musical. Based on popularization of the new musical-dramatic genre, there appears a new fusion of art and production, management, advertising and mass media. Amongst these, the problem of performing mastership of musical actors in Kazakhstan is being studied. The aim of the article is to achieve a theoretical discourse of particularities, history of development and popularization of the new scenic genre of musicals. The task of the investigation are studying the activity of the founders of musical, collation and analysis of works, theories of theatrical art, anthologies, memoirs, articles and theater productions; assessment of musical and autonomous art forms (synthesis of acting art, choreography, singing, stage design, drama, music composition); analysis of characteristic of the activities of the musical founders (Leonard Bernstein, Andrew Webber, Riccardo, Richard Rogers, Irving Berlin, Cole Porter).The result of solving these tasks should be the formation of the cohesive picture of the history of the development of the musical, as well as its current position in the arena and in the Kazakh theatrical art. The study will be appreciated by directors and other theater specialists who wish to find information on the overall perspective of the musical and musical theatre, as well as by music and theatre critics seeking a balanced assessment of theatrical synthesis. Some fragments of this investigation could be included into University courses on history and theory of musical theatre.
\end{abstract}

Keywords: musical, music theatre actor, singing, performance.

\section{INTRODUCTION}

At the present time, musical is one of the most popular genres of commercial music at the junction of the socalled popular and academic arts. The genre is complex, synthetic, in relation to which currently there is no consensus in science.

The search for new forms in the history of the musical

If we refer to encyclopedia, we will find the following definition in it, "Music-scenic genre, employing expressive means of music, drama, choreography and opera arts. Their combination and interconnection gave special dynamics to musical; a characteristic feature of many musicals is solution of complex dramaturgic tasks through artistic means not difficult for perception" [1, $p$. 368]. In our point of view, the definition is at large correct, it comprises specifics of one of the youngest genres of contemporary musical theatre, but together with it, to a certain extent, it is somewhat cumbersome and ambiguous. A string of questions appear here as long as it refers to a new genre. It is notable that the author of the 
work on the Russian musical for adults and children, A. Bakhtin asserts that "a musical is the most unstudied one of all the music-drama genres, the genre and aesthetical specifics of this interesting scenic phenomenon have not been defined yet, its main genre characteristics have not been outlined either. Unclear, ambiguous is the definition of a musical as well: operetta, musical comedies, rock operas, Song-operas, and pop operas are commonly referred to this genre. No other musicdrama genre of the second half of the $20^{\text {th }}$ century could ever be more many-faced and provocative ." [2, p. 4]. There is a clash of opinions in defining a musical. At the same time, musicologists and theatrical experts reach consensus in the identification of tendency towards synthesis, wide and organic deflection of certain principles typical for many theatrical genres. So, N. Yenukidze writes that the sources of a musical are rooted in the 20-30-ies of the $20^{\text {th }}$ century [3, p. 63].

Having formed in the United States of America in the first decades of the $20^{\text {th }}$ century, the musical concentrated in itself the essential features of the main musical and theatrical genres of the North America. Thus, from the ballad opera the musical gleaned the aspiration for the exploitation of the "refreshed" historical plots or of those classical literary works, and the aspirations for stable relations with the city song folklore. From "the minstrels' theater" into the musical there were transferred the practices of the diverse variation of thescenic types "masks", of improvisational creation of colloquial scenes and "the Black manner" performance of song numbers. From extravaganza, French by the origin, there resulted the inclination towards fabulousness, "magic quality" of the dazzling colourful performances - the enchanting spectacles sated with melodramatic collisions, scenic effects, grandiose scenery and suits, circus attractions, and also numerous dancing numbers. Parody-travesty burlesque introduced into the musical the sharpness of interpretation of the today political and social problems, the particular raciness of the speech characteristics, the purposeful shortening of the distance between the scene and the auditorium, introduction of the "interactive" methods enabling the involvement of the certain "segments" of the audience into the action. From the American vaudeville genetically connected with the English music hall, there were inherited the priority role of the image-emotional atmosphere as the fundamental factor of the theatre integrity, the dictatorship of the scenic rhythm, the purposeful coordination of the visual and acoustic plans of a performance, performers' universalism. The revue genre appeared to be the musical anticipant in terms of the interpenetration and synthesis of heterogeneous elements with the external absence of the pass-through dramatic action and the of subject integrity, having been compensated thanks to the unity of higher level: ideological and thematic, figurative and semantic and musical- stylistical [12, p. 67]. The musical is one of the most fashionable genres of modern music theatre. Some consider it as the American kind of operetta. This is conditioned by that that it is characteristic of the art genres to evolve, to change its national and genre specifics. The criticisms like, "this is not an operetta" were familiar to many operetta authors of the $20^{\text {th }}$ century. But it is in the American musical theater where there was the quality leap, which allows many to consider the musical as a scenic genre, although located in the relations of close kinship and continuity with the operetta [13, p. 84].

It should be said that the majority of the Russian researchers studying the problem, E. Kampus, N. Yenukidze, I. Syssoyeva, Ye. Andryuschenko, tend to treat this historical way within the frame of several periods, specifically up to date, of six periods. For us it is important that in all the sources, the authors have a single point of view: the frontline is quite clear, as the point of reference chosen is a socio-historical moment. That is, first of all, changes in the socio-political life of the country, in the second turn, - the cultural needs of the American society.

The first period; In theatre criticism it is accepted to think that the musical genre originated somewhere between the 1900-1910 years, there are no exact date and common opinion on this occasion. That is, one must take note that there was needed a temporary distance of a quarter of a century until the previous forms of conglomerate formed the purely American musical comedy. This was followed by another quarter of a century, until it was formed as an independent musical theatre form, grown on the American soil and meeting up the psychology, the world perception, the rhythm and lifestyle of the Americans. Such development was unlikely to occur spontaneously, it was directly dependent upon the requests of "the market". In deference to the worries of the day, reacting and accurately complying and passing the mindset of mass audience, the musical, to a large degree, reflects the picture of the social life of the country.

In the 1900-ies American musical theater, of course, was under a great influence of the European Theater. Firstly, the young composer national school (YNCS) was in its infancy. Secondly, there lived the largest European musicians, and many American composers, had a European education and they actively developed the new genre. Originally, under the huge influence of $F$. Legard, I. Kálmán, as the researchers note, they have created a musical performance, in the spirit of the romantic Viennese operetta. Almost at the same time there were musical comedies, revues, with strongly pronounced national start. The musical-theatre productions of the years 1910-1915. These are operettas - "Naughty Marietta" by Victor Herbert, "Madame Sherry" by K. Hoshna, "The Firefly" by Rudolf Friml, "The Blue Paradise" by Z. Romberg, "The Girl from Utah" by J. Kern, musical revues - "Watch Your Step" by I. Berlin, F. Ziegfeld, musical comedies - "La, la, Lucille" by George 
Gershwin, "Hello, Broadway!" and "The Little Millionaire" by George M. Cohan, and also, intimate musicals, that were on under the common name of "Princess Theatre Show". Despite its shortcomings in plot, text, outspoken entertainment, performances had stunning success with the audience.

Summarizing, we can say that reliance upon and wide use of the specific elements of operetta, musical comedy, revue, vaudeville, extravaganza, the pinning characteristics such as relevance, patriotism, the Americanization of the plot and style, dominating conversation, active involvement in the musical arsenal of the contemporary urban songs becomes crucial for the first period in the development of the musical.

The second period was the 1920-1930-ies. This was the time of the World War First, rapid economic development, the prosperity that followed the end of the World War First. This situation contributed to the present explosion in the theatrical industry of the United States when there is demand for all kinds of entertainment arts. This period saw the emergence of an all-out passion jazz, variety and upscale dance orchestras, musical sound recordings, radio broadcasting. The Broadway stage is thriving. Ziegfeld's "Follies" compete in its scope with George White's "Scandals" and Shubert Brothers' passing-shows. On the other hand, "Garrick gaieties revues chamber" and "the Grand Street Follies" are gaining popularity though not as spectacular, but more refined in artistic terms.

Still popular are the operetta, both European and American. There were created the best compositions in this genre, by Rudolf Friml: "Rose-Marie" (1924), "The Vagabond King" (1925), "The Three Musketeers" (1928), and by Sigmund Romberg: "The Student Prince in Heidelberg "(1924)," The Desert Song "(1926) and" The New Moon "(1928). In the field of musical comedy there were intensively employed such composers as Jerome Kern, George Gershwin, Vincent Youmans, with debut acting performances by Richard Rodgers, Cole Porter.

Only in the 1920-ies on Broadway, more than 400 musical comedies saw the ramp light, a good half of them survived over 500 performances each. Most of the musical comedies were superficial, purely entertaining works designed for the simplest tastes. The librettos were typical banal half-hour sketches (Sketch (Eng. sketch, literally - draft, drawing, lines), in the XIX - early XX cc., a short piece with two or three (more rarely) personages. Sketch gained most popularity on the stage). The score usually consisted of separate melodically pleasing, not of a music chain. And, although some authors sought to link actions, text and music more, the musical comedy in artistic terms of those years in general, yields to the operetta with its expanded musical forms and proven dramatic standards. In the general background of Broadway, the musical comedy is dramatically outshone its seriousness and non-traditional approach to the genre in "Boat Show" (1921) by Jerome
Kern, M. Ettinger refers to it as "the first truly American musical". Among the other works of this period, there could be mentioned musical comedy "A Connecticut Yankee (1927) by Richard Rodgers, based on the novel by Mark Twain's "A Connecticut Yankee in King Arthur's Court". We shall especially note that this was the first one experiment in the "Broadway" experience with literary classics being the basis of musical performance. In sum, we shall say that the second period (1920-1930-ies) was marked by the spectacular "breakthrough" in the entertainment industry, the adoption of the fundamental principles of show business and generated by the commercial musical theater. A tremendous musical and musical film competition promotes the enrichment of expressive means, adaptable theatrical performance; enhance ideological and topical range, increasing the role of synthesizing trends in the development of the genre (musical-drama, musical, ballet, etc.). In the field of musical stylistics, the dominating trends are due to the influence of the style of jazz, interacting with the academic musical forms and compositional principles.

In the third period of musical history - the 1940-ies there was a special period in times of crisis. It is closely related to the economic situation in the United States, and, above all, with the stock collapse in October 29, 1929. Dramatically different socio-economic situation in the country, most of society lost their jobs, there started the great depression in the community. Naturally, the Broadway theaters were empty; people were not interested in entertainment. According to statistics, in the 1930-1934, the 12 Broadway theatres were closed, many of them forever: in the 1935-1940 , with Broadway about a dozen more disappeared, others were converted into a textile factory, a car park, rebuilt for the film and radio studios. The development of sound film and the massive proliferation of radio even more complicated the situation on Broadway. Well-known cultural figures were forced to work in Hollywood. It turned out that the film adaptation of the musical comedies in 1920 -ies was popular with the public. It was enough to put into the movie the old operetta, musical comedy, revues, and for them it was a rebirth. Soon they began to create music movies based on the original scripts with the music specially written to them. There appeared a new genre the cinema musical. Because the best composers and scriptwriters had been recruited by the cinema, theatrical musical led lowlife.

Started the update of the genre, there were launched the satirical musical shows like "Strike up the Band (1930) and "Of Thee I Sing (1931) by George Gershwin. The desperate machinations of liberalism, capitalist moneymakers, the electoral system and political institutions of the United States were mocked at. Not by chance the libretto musical "Of Thee I Sing" was awarded the Pulitzer Prize. The composer Leonard Bernstein, who was actively engaged in critical activities noted: this was a work unparalleled in content, both comic and dramatic. 
Such performances we have not seen yet. Captivating melody completely merged with the action; the theme is a typical American one; correct is the American language; shiny polished text; unity of music style hides a huge change of sentiment, and a wealth of moods, to put it shorter-this show was a high point in the history of our music".

This line was followed in musicals by other authors. Up-to-date start, satirizing are inherent to musical comedies - the political-satire revues of "Face the Music" by I. Berlin (1932), "Johnny Johnson" by Kurt Weill (1936), "On the Pins and Needles" by Harold Rome (1937). Topical issues related to the labor movement, the musical drama "The Cradle Will Rock by Marc Blitzstein (1937), is dedicated to it, and, of course, they were helped to be brought into being on its way to the Viewer to actively opposition of the Government. A significant milestone in the history of the American musical culture was the brilliant Opera "Porgy and Bess" by George Gershwin (1935), having had a major impact on the development of the musical. Thus, the specificity of this time is determined by the variety of creative searches, which are increasing synthesizing processes inherent in the musical: its interaction with people's musical drama is caused by the birth of "folk opera", assimilation of chamber genre features a lyrical-comic psychological drama, and great romantic opera of the $19^{\text {th }}$ century, the opera - the social drama of the first third of the $20^{\text {th }}$ century is the emergence of "light genres". High intensity was reached by the integration processes between the musical and ballet which is most clearly embodied in the works of Leonard Bernstein.

The fourth period in the development of the genre, according to historians of the musical, landmark the 1950-1960-ies period, and it is associated with the premieres of three talented works. The first musical was "Cabin in the Sky" by Vernon Duke, who introduced Broadway with the American Blacks' folklore and fantasy world. The second is "Pal Joey" musical by Richard Rodgers based on the short stories by John O'Hara, where the hero, contrary to the traditions of the genre is a negative character - one managing a night club and a pimp. The third musical, authored by the "Lady in the Dark" by Kurt Weill first brought to the American scene the theme of psychoanalysis (Weill, Kurt. - a famous German composer, songwriter, author of choral and theatrical works, was forced to move and work in the US).

A major milestone in the history of musical theater was the premier of "Oklahoma!" by Richard Rodgers (libretto and lyrics by Oscar Hammerstein). "Reflecting one of the myths of American society, the sponsors of the show recreated the idealized image of America, poetized of the pre-industrial times, drew solid and independent characters, the sincerity and directness of human relations", writes A. Orelovitch. Some critics are right in drawing the analogy of the musical comedy with the opera, defining it as "the people's opera". The Civil War
America (1861-1865) and of the subsequent decades of the $19^{\text {th }}$ century once again comes alive in the musical comedies of "Bloomer Girl" by Harold Arlen (1944) and "Annie, Get Your Gun" by I. Berlin (1946). Cole Porter's pinnacle was "Kiss me, Kate!" musical (1948) based on the comedy "The Taming of the Shrew" by William Shakespeare. A number of musicals of the decade, to varying degrees, involved the pressing social issues and, in particular, typical for this country's racial problems. So, in the musical "Finian's Rainbow" by Burton Lane (1947), the racial theme takes the form of the folk legend. In "Bloomer Girl" it occurred against the background of the events of the past. In "South Pacific" musical by Richard Rodgers (1949) there were the current events of World War second. In the "Allegro" musical by Richard Rodgers (1947) there were discovered the soulless machinery of profit and success in the modern society. The German composer Kurt Weill's musicals, he emigrated to America during World War II, were usually called the musical dramas, "Street Scene" (1947) and "Lost in the Stars" (1949), they depict the slums of New York City and one of the South American race jungles.

Simultaneously with the expansion of the musicals and their form improved. Such organic synthesis of the intrigues, music, dance and dialogue, which was achieved in "Oklahoma!", the American musical theatre did not know yet. We had that in those years of the growing significance of the musical idiom of dance, as well as increased attention to plastic means of expressiveness [12, p. 300].

Although Richard Rodgers, Lorenz Hart and George Balanchine's attempt made ballet party the events, included it in the motion referred to in the 1936 "On Your Toes" musical. The popularity and success of musical authors and producers had to keep looking in that direction. Following the "Oklahoma!" the special role of the ballet in the "On the Town" musical comedy (1944) was highlighted by Leonard Bernstein. There will be another thirteen years, the so-called "balletization" of the musical reach its peak in his "West Side Story".

In the history of the development of musical, 50-60 years of the century are considered to be a period of maturity, it is called "the golden age" of the musical creation time, the classic designs of the genre [10, p. 6].

Significantly enriched and broadened its scope, defined the boundaries of the genre. The creators of the Broadway performances were subject to the most ambitious, creative embodiment of imagination and daring designs. At this time there were musicals and dramas based on classical contemporary novels, stories, and movie scripts were created for audiences. So, for example, Marcel Pagnol's Trilogy about Marius inspired the appearance of "Fanny", from "Pygmalion" by George Bernard Shaw получилась "My Fair Lady", from "Romeo and Juliet" by William Shakespeare - "West Side Story", from Eugene O'Neill "Anna Christie" drama -"New Girl in Town". The circle of more talented directors considerably 
widened, thanks to the improved designs of the artistic level of performances. In this regard, the researchers isolated a specific trait of that that the composers, choreographers and librettists often acted as the stage directors and, being more often the co-producers. So, the composer Jule Stein simultaneously appeared in the three guises: he was the musical producer, composer and co-producer and director in one face. It can be said that the practice was typical for Broadway, where the author of the text, the composer and actor were combined into one. Such generalists were the famous composers- George M. Cohan, Cole Porter, Irving Berlin, Frank Harry Loesser, Harold Rome and others.

From musicals produced in the 1950-ies, world renown on the theatrical stage, and then movie conquered were "My Fair Lady' by Frederick Loewe (1956), "Wonderful Town" (1953), "Candide" and "West Side Story" by Leonard Bernstein (1957), "The Sound of Music" by Richard Rodgers (1959). In the 1960-ies exceptional success was with such works as "Hello, Dolly!" by Jerry Herman (1964), "Fiddler on the Roof" by Jerry Bock (1964), "Fantasticks" by Harvey Schmidt, (1960), "How To Do Business Without Really Trying" by Frank Loesser (1961), "Man of La Mancha" by Mitch Leigh (1965), "Cabaret" (1966) and "Zobra" (1968) by John Kander, "promises, Promises" by Burt Bacharach (1968) and, finally, in the wake of the youth movement of the restless years "Hair" rock-musical (1968) by Galt MacDermot (libretto by Gerome Ragni and James Rado)( The musical was a musical-theatrical review, in which naked actors and actresses acted). [9, p. 47]. Thus, in the 1960-ies, as the highest point in the development of the American musical, it at the same time marked the beginning of the crisis, facilitated the creative advancement in the field of musical theatre.

The fifth period (late 1960-ies-1970-ies) in the American musical, the two are the clearly pronounced trends. The first is a conservative, aimed mainly at entertainment, proven designs and style of the previous decades. The second is the "avant-garde", the acute and pressing the issue and talking to the audience mainly in the language of rock music. Naturally, it is the first trend that is the dominant and is more widely spread. The latter was due to the fact that the main bet was made on commercial calculation, the conservative tastes of the socalled "middle class", that is the petty-bourgeois audience, the decline of radical left movement waves.

A striking example of realistic works, which reflected the events of modern American reality, is created in 1970 "The Nobody Knows Me" musical (text by Herb Shapiro, lyrics by Will Holt, music by Gary William Freidman). The spectator is deployed in many of the tough terms though the documentary narrative about the life of the children of the slums and ghettos. Not coincidentally, researchers here parallel it with "West Side Story" by Leonard Bernstein. In general, the researchers note that it was the period where thematic and genre diversity were inherent to musicals. These works includes; the sentimental comedy about the popular comic strip heroine Little Orphan Annie and her devoted puppy Sandy (1977, text by Martin Charmin, music by Charles Strouse),"Sweeney Todd" musical, the apparent effect of the theatre of horror, as his main character trades his food made from the meat of dead people (1979, libretto by Hugh Wheeler, music by Stephen Sondheim). At the same time, along with the interesting theatrical productions on the modern theme, the audience got a chance to meet "historic"costume" musicals of Charlemagne (King Charles) "Pippin" (1972, with music by Stephen Schwartz) and Henry VIII - "Rex" (1976, with music by Richard Rodgers), and also "The Two Gentlemen of Verona" by William Shakespeare (1971 with music by Galt MacDermot). [9, p.15].

The musicologist E. Andryushchenko emphasizes that the phase was marked by crises and the dominated the "avant-garde" and "traditionalist" directions opposition in the genre. Legacy of the "avant-garde", which poses to show actual problems of youth and interaction with the newest currents of mass musical culture (rock- and popmusic), in general, have failed the test of time. However, the best designs of rock-operas and rock-musicals of this period affect the trunk roads to the "light genres" development of the musical theatre. "Traditionalist" for demonstrating creativity and high level of professionalism, par excellence, as noted by $\mathrm{A}$. Orelovitch, "drawn in the past", which explains the "secondary" series of musicals of the period. According to the researchers, the prospects of a genre defined by creative "dialogue"-the interaction of the above trends appeared in the works of English composer Andrew Lloyd-Webber of late 1960-1970-ies "Joseph and the Amazing Technicolor Dream coat", "Jesus Christ, Superstar", "Evita".

The sixth period falls on 1980-1990-ies. Having first appeared in American culture, the musical quickly spread in other countries - France, England, Poland, Sweden, Russia, Kazakhstan, and also in the countries of the Eastern continent, gaining immense popularity among a broad audience.

At the turn of the $20^{\text {th }}-21^{\text {st }}$ centuries the musical comes to stand the uncompromisingly "globalist" aspirations of modern mass culture with the adoption of effective business-technology in modern musical theatre. In addition, there is a growing tendency to assimilate different musical elements of academic music-operas, cantatas, oratorios, magnitude of the ambition and complexity of compositional drama. The epitome of synthesizing trends in musical of this period, according to the researchers, are the works of Andrew Lloyd-Webber, Riccardo Cocciante lyrics, A. Cohen, L. Chedid and other outstanding composers, displaying specificity of this genre and race teams representing its top achievements.

In general, despite some successful European productions, the European musical is not yet able to 
compete with the American production. There are several reasons to this. At the European theatres there are not enough actors who have both the vocal and acting skills at a master's level, and at dance, and even at acrobatics. In the United States the commercial theaters make huge efforts in search of such actors. The European theatres with the permanent actors' staff have to be satisfied with the actors who are currently in the troupe. And while a bad singing actor is sometimes more suitable for a musical than an operetta actor, due to lack of orchestra, choir, dancers, staging musicals in theatres is not widespread. The European orchestral musicians generally do not have the style and rhythms of jazz and modern dance music. For all the foregoing reasons, attempts by domestic theatres to copy foreign productions have not yet reached the Broadway level. Some theaters have invited American conductors, but there was not a big benefit from this. There was not solved the problem by the attempts to invite jazz musicians for performances on the percussion instruments. The creative process of creating the musical in Europe is different from how it is done in America, and it is often divided from the collective of artists without trial performances, corrections and additions that take into account the reaction of the audience. For all the foregoing reasons, attempts by the European theatres to copy foreign productions have not yet reached the Broadway level. [9, p. 37].

The main structural difference between these genres and a musical is determined by the role assigned to music in comparison with dramatic scenes. The author of the book "The World of Operetta" writes, "Operetta, which the European classics of the genre sought to bring close to opera, largely preserved the features of seasoned musical form with its ensembles and finals, with leitmotifs and elements of symphonic development. The musical is more of a theatrical form in which music is a means of musical and scenic montage along with choreography, plasticity, stage effects, and so on." [5, p. 32].

One of the distinguishing features of a musical is the high literary level of most musicals. It is largely determined by the fact that that story basis for them is taken from well-known but sometimes just brilliant works of classical and contemporary literature. The primary sources for musicals were works by Victor Hugo, William Shakespeare, Miguel de Cervantes, François Voltaire, Charles Dickens, Bernard Show, Ferenc Molnár, Solomon Sholem-Aleichem, Eugene O'Neil, and contemporary American authors, Mark Twain, Truman Capote, Thornton Wilder, Anne Rice, Maxwell Anderson and others. The best musical librettos are distinguished for interesting problematic issues, original characters, brilliant dialogues, effective culminations, highly poetical verses [6, p. 5].

Over just a century a musical has been changing and it is changing at the moment, the search for new forms lead to many faces and many facets of this entertaining genre. Musical addresses its audience in the language of contemporary every day and pop music, in which extended episodic finals are present, songs are dominant, ensembles are rare, but solo scenes or scenes by several soloists are frequent. Intense action is characteristic of the musical. Everything is governed by it: every remark and musical episode, any dance pas and comical reprise. Vocal and dance scenes have to directly grow out of an action and to develop it. They have to be considered necessary, in other words, internally motivated [7]. It is well known that opera and operetta got the audience used to ballet scenes of a divertissement type: sometimes these are private suites, sometimes whole suites, terminating development of the main intrigue. The musical, in its best samples, links such scenes with the plot, with the development of characters. Ballet episodes here are no longer inserted pieces, they are part of the action and choreography, the plastics becomes a vital part of the expressive means of the musical, along with singing. Musical pieces are generally handled well and plastically. Characters are revealed both in singing and dancing.

In opera and operetta a ballet master-choreographer typically performs a more or less important, but still a secondary role, confined to ballet episodes and the socalled backup dances. In practice of musical staging, he is often actually the second or even the chief stage director. For instance, the famous American choreographer Jerome Robbins was an initiator and made the first staging of "West Side Story", then directed "Fiddler on the Roof", "Funny Girl". Holistic choreographic solution, virtuoso plastic figures make up the most impressive part of the best Broadway musicals [8, p. 46]. Conceding operetta in intensity of vocal usage, a musical, however, pays much more attention to the plastic expressive means. This fact, alongside with the careful designing of the dramatic line imposes special requirements to the art of a musical actor. The ideal here is a combination of the qualities of an actor, singer and dancer - an extremely rare complex. The musical is designed for universal actors, those possessing the ability to synthesize, integrate various kinds of professional skills - to act on stage as a dramatic actor, have professional vocal skills, be proficient in dance, plastic arts, subjecting them to a single line of stage behavior, t. i. the task of creating an integral image. This aspect notably is of the most important ones when staging performances of this genre.

It is important to note that the staging of the musical is very beneficial not only business-wise but also in creative terms. Creative advantage is in that the troupe can be formed only at the time of performance staging. In this creative process actors (participants) show their skills and abilities, competition grows inside the team, which is an impetus to improve performance of the role. In this respect the Kazakh scene is not an exception. But, unfortunately, up to day the desired result has not been 
achieved yet. In the neighboring countries, like Russia, the staging of the world known musicals took place, "Notre-Dame de Paris" (1998) by Riccardo Cocciante, "Romeo and Juliet" (2003) by Gérard Presgurvic, "Jesus Christ Superstar" (1998), "Cats" (2005) by Andrew Lloyd Webber and others. And also very successful were the staging of domestic performances such as "Krechinsky's Wedding" by Alexander Kolker, "The Star and Death of Joaquin Murieta" and "Juno and Avos" by Aleksei Rybnikov, "Nord-Ost" by Aleksei Ivaschenko and Georgii Vassiliyev and others. Staging of this sort are on at the Russian theaters for tens of years which of course provides a creative group, actors participating in these performances in the first turn, with huge experience. For example, in the "Juno and Avos" performance by Mark Zakharov the role that had been performed by Nikolai Karatchentsov for many years has been performed by Dmitri Pevtsov for the past several years. So, in this way actors of several generations heighten their professional level by prolonging the life of the "performance of many years of age".

Speaking of the musical theatre actor's upbringing in Kazakhstan, we shall remind you that in the process of staging a commercial project of the musical "Zhibek» by producer V. Rakhysheva and young composers S. Shamenova and D. Rayeva, the problem was in the professionalism of the actors' troupe. Initially a casting for all parts was held, which gathered the acting troupe. It included actors of drama theatres, pop singers and ballet dancers of the Abai State Academic Opera and Ballet Theatre. In the history of the musical, there are numerous examples of productions in which personalities of different types of art took part. For instance, the cast of one of the most popular musicals, "Notre-Dame de Paris" was comprised of pop singers: Bruno Pelletier, Hélène Ségara, Garou and others, who are professional singers. However, at the first night of the performance, not only vocal and acting techniques, but also choreography won the world's recognition.

The problem of staging the "Zhibek" musical was in that that the professional theatrical actors had high command of acting mastership but lacked vocal mastership. On the contrary, pop singers did well in vocal parts, but lacked mastership in acting techniques. In this situation, for stage directors it was not possible to comprise the troupe of only just actors and singers due to the reasons of commercial and artistic character. To resolve these problems, it was decided to increase the time of actors ' vocal rehearsals, as well as an overview of lessons in acting art for pop music performers which significantly improved the production process. However, not all the problems were solved.

In our point of view, the reason to the shortage of professional staff is inadequate training. Thus, the question is in the educational process of future musical theatre actors. To date, at the universities of Kazakhstan the problem is in teaching, not fully meeting with the requirements of the modern theatre.

At the Zhurgenov National Academy of Arts, professional musical theatre actors have been prepared since 1979. Musical comedy chair was founded by the People's artist, professor, soloist of the Abai State Academic Opera and Ballet Theatre, movie actor $\mathrm{K}$. Kenzhetayev, who by his resourceful labor, indefatigable energy gathered a collective of like-minded persons. The instructors P. Ildarov, R. Mashurova, M. Zhunuss, G. Gizatova, Ye. Segizbayev, P. Dorokhova, N. Radtchenko, A. Sembin founded the methodical basis for preparation of musical-dramatical theatre specialists. The training programs were based on the programs of the leading drama schools of the Soviet Union, such as GITIS and LGITMIK. The first graduates of 1984 were performers famous now - the People's artist of the Republic of Kazakhstan R. Rymbayeva, the honored artist of the Republic of Kazakhstan M. Iliyassova. The graduation performance of the course was the performance "Arshin Mal Alan", staged by the motifs of the musical comedy under the same name by the Azerbaijan composer $U$. Gadzhibekov, the students were taught by Professors K. Kenzhetayev and R. Mashurova. The next graduates, the course by Ye. Segizbayev, brilliantly performed "Silva" by Imre Kálmán at the stage of the Abai State Academic Opera and Ballet Theatre.

During the existence of musical comedy chair there have been staged many foreign operettas- "Mam'zelle Nitouche" by Hervé (course by Professor R. Mashurova), "The Bat" ("Die Fledermaus") by Johann Strauss (course by Professor Ye. Segizbayev), "Silva" by Imre Kálmán (course by the People's artist of the Republic of Kazakhstan, Professor Ye. Obayev), vaudevilles - "Khanuma" by Giya Kancheli (course by Instructor Ye.Tokeyev), "Arshin Mal Alan" by U. Gadzhibekov (course by Professor K. Kenzhetayev), musical comedies - The Marriage of Figaro" by Beaumarchais (course by Professor R. Mashurova), "Cinderella" (course by Ye. Karibayev), musicals - at the stage of the training theatre there were staged "Sister Cary" by Raymond Pauls, "West Side Story" by Leo Bernstein (course by Zh. Khadzhiyev), "Cats" by Andrew Lloyd Webber (course by T. Omarov).

It should be noted that for a musical theater actor ,a narrow command of only academic vocal is not sufficient for full professional realization, since in modern musicals there are different genres of music such as pop, jazz, folk music, rock. Based on this fact, derived from world experience, musical theater actors have to be fully prepared for singing in different musical genres. Following world standards in training, educational program at domestic higher educational institutions need the introduction of additional disciplines in vocal training, and these are jazz-vocal, folk and pop singing.

In 2007 the students at the master's workshop by 
Professor R. Mashurova staged the musical "Notre Dame de Paris" by Riccardo Cocciante and Luc Plamondon. The performance was organized by the students' own creative efforts. And the first challenges encountered when setting the performance were vocal and choreography since the difficulty was in the process of singing and dance compatibility. As the "Notre Dame de Paris" musical is also considered a rock-opera, the main problem for the performance participants was the requirement of pop-rock singing. For instance, in the French version of the performance the leading soloists were professional rock performers: Garou, Bruno Pelletier, and Daniel Lavoie. And only solid academic preparation helped them cope with this complex composition.

On the experience of the Moscow Theatre Universities where all kinds of vocal are taught, academic, folk, jazz and pop vocals are taught separately. During the "Music in theatre - Theatre of music" master classes (2008) at the B. Schukin Theatrical Institute, students fully demonstrate their skills. At the first year at the institution folk singing and academic vocal are concurrently taught. The second year is devoted to pop vocal, and the third to jazz vocal. Academic vocal is taught beginning from the first and up to the last years. And I have to say that this training is a must. For example, the "The Phantom of the Opera" musical by Andrew Lloyd Webber requires academic vocal, "West Side Story" by Leo Bernstein - jazz vocal, and the musicals by Gérard Presgurvic "Gone with the Wind", "Romeo and Juliet" require pop vocal. However, there are stars such as Julie Andrews, for example, Sarah Brightman, Lea Salonga, Bernadette Peters, who are inspired by the images of very complex parts of different genres. This is the versatile preparation that provides for the desired result required for a highly professional artist. Thus, we can say that musical theatre today has become one of the "high arts", along with opera and ballet.

\section{CONCLUSION}

In general, despite some successful productions, a musical in Kazakhstan is not yet able to compete with the American and European products. There are several reasons to this. At our theatres there are not enough actors who have both the vocal and acting skills at a master's level, and at dance, and even at acrobatics. In the United States and Europe commercial theaters make huge efforts in search of such actors. The Kazakh theatres with the permanent actors' staff have to be satisfied with the actors who are currently in the troupe.
And while a bad singing actor is sometimes more suitable for a musical than an operetta actor, due to lack of orchestra, choir, dancers, staging musicals in theatres is not widespread. Orchestral musicians generally do not have the style and rhythms of jazz and modern dance music. For all the foregoing reasons, attempts by domestic theatres to copy foreign productions have not yet reached the Broadway level. Yet the musical in Kazakhstan exists and develops.

By studying the works of past theatrical artists and artists of our time, by analyzing trends in entertainment art direction, you can assert that a musical genre is to have a very big future and long history.

\section{REFERENCES}

The Encyclopedic Musical Dictionary. - Moscow (1986). - p.368;

Bakhtin A A Synthesis of arts as a basis for musical for adults and children. An author's abstract for obtaining PhD degree in Arts Studies. - Moscow, 2006. - p.4;

Yenukidze N I. The Popular Musical Genres. // From History of Jazz and Musical. - Moscow, 2004. - p. 124;

The Greatest Musical of the World: Popular Encyclopedia. - Moscow, 2002. - p.84;

Zhukova L. In the World of Operetta. - Moscow, 1976. - p.32;

Syssoyeva AV. The Broadway musical. The Process of Formation of the Genre in the $20-30$-ies of the $20^{\text {th }}$ century. An author's abstract for obtaining PhD degree in Arts Studies. Moscow, 2005. - p. 22;

E-source: http://www.musicals.ru;

Bushuyeva SK. Musical // Arts and masses in the contemporary bourgeois society: St. Petersburg. State Scientific-Research Institute of Art Studies. - Moscow, 1979. - p.46;

Actor and director: life in the theatre. The social problems of the two decades. Moscow, 1991.

Zhurbin A. How it was made in America. Autobiographical notes. Moscow, 2005;

AndryushchenkoYe. Yu. The musicals by Andrew Lloyd-Webber of late 1960ies-1980ies. The Auto-reference of the thesis for obtaining the Candidate of Art Studies scientific degree. Rostov-upon-Don, 2007.- p. 6;

Orelovitch A. Operetta// The foreign music of the $20^{\text {th }}$ century. Moscow, 1980, Volume II, book 3. - p. 300;

Yenukidze N I. The popular music genres.//From the history of jazz and musical. - Moscow, 2004. - p. 124;

\section{APPENDIX}

1. An Interview with a Professor of the Zhurgenov National Academy of Arts M. O. Zhunuss.

2. An Interview with "Zhibek" Musical Project producer V. Rakhysheva.

3. An Interview with Master of Arts, theatre and movie producer A. Samakhanov

How to cite this article: Khalykov $\mathrm{K}$ and Nurtazin $\mathrm{Y}$ (2013). Modern theatre: actor's musical requirements in the educational process of Kazakhstan. Int. Res. J. Arts Soc. Sci. 2(9):220-227 